\title{
Mutational analysis of Chk1, Chk2, Apaf1 and Rb1 in human malignant melanoma cell lines
}

\author{
THILO PAPP, ANNETT NIEMETZ, NILS DOSDAHL, KRISHAN KUMAR and DIETMAR SCHIFFMANN
}

\author{
Department of Biological Sciences, Institute of Cell Biology and Biosystems Technology, \\ University of Rostock, Rostock, Germany
}

Received June 28, 2006; Accepted August 14, 2006

\begin{abstract}
Four tumour suppressor genes (Chk1, Chk2, Apaf1 and Rb1) in nine human malignant melanoma cell lines were screened for a loss of gene expression, point mutations and small deletions/insertions by cDNA-based DGGE/SCCP analysis. In two cell lines alterations of the investigated genes could be demonstrated. This result confirms our assumption of the participation of dysfunctional p53 inducer/effector genes in human melanoma aetiology. Furthermore, it points towards the probable principal role of diverse alternative p53-pathway disruption mechanisms in this highly therapy-resistant malignancy without affecting p53 itself. To our knowledge, this is the first CHK1/CHK2 mutation screening in human melanoma.
\end{abstract}

\section{Introduction}

The DNA damage checkpoint pathways link the detection of DNA damage to the inhibition of cell cycle progression and subsequent DNA repair. Consequently they also support the maintenance of general genomic stability. The protein kinases Chk1 and Chk2 as well as the cardinal tumour suppressor gene (TSG) p53, in alliance with its important effector Rb1, are central players in this checkpoint activation. When DNA is damaged beyond repair, the initiation of a permanent cell cycle blockade (cellular senescence) or even the total elimination of the respective cell by programmed cell death (apoptosis) is executed via the activation of the p53 effector Apaf1. Chk1 and Chk2 form the core module of the DNA-damage-response network, into which signals from sensory components of the pathway flow and from which the activation of the effector components emanates.

The Chk 1 protein is activated by its phosphorylation at Ser-345 and Ser-317 by the protein kinases ATM and ATR in response to various types of DNA damage, which can be

Correspondence to: Dr T. Papp, Department of Biological Sciences, Institute of Cell Biology and Biosystems Technology, University of Rostock, Albert Einstein Strasse 3, 18051 Rostock, Germany

E-mail: thilo.papp@biologie.uni-rostock.de

Key words: human malignant melanoma, Chk1, Chk2, Apaf1, Rb1, SSCP, DGGE induced by IR, UVR, ROS or diverse chemical mutagens (1-4). Activated Chk1 in turn phosphorylates the phosphatase CDC25A at Ser-123, which then leads to the inactivation of CDC25A through ubiquitin-dependent degradation (5). Consequently, CDC25A can not dephosphorylate and thereby activate $\mathrm{CDK} 1$ and $\mathrm{CDK} 2$. In the end, the non-activated CDK2 and CDK1 proteins cause S/G2 phase arrest (6).

Chk2 also functions as an S/T kinase. Like Chk1, Chk2 is activated by its phosphorylation in response to various DNA damaging agents (7-9). This phosphorylation is primarily mediated in vitro and in vivo by ATM at threonine 68 of Chk2 (10-12). However, ATR also phosphorylates this site and regulates the response of Chk2 to UV light. Although Chk2 is structurally distinct from Chk1, both enzymes display a partial overlapping substrate specificity (13). Like Chk1, activated Chk2 phosphorylates Ser-123 of CDC25A, which then also leads to $\mathrm{S} / \mathrm{G} 2$ phase arrest. However, in contrast to Chk1, the cardinal role of Chk2 is the initiation of DNA damage-induced cell cycle arrest at the G1/S checkpoint or apoptosis via the direct activation of p53 (14). Activated Chk2 can directly phosphorylate p53 on Ser-20 in vitro $(15,16)$. This phosphorylation prevents the binding of p53 to the ubiquitin ligase MDM2 and thereby avoids its degradation (17). Genetic evidence for the essential functional relevance of Chk2 at the p53 signal transduction pathway is further provided by the identification of Chk2 germ line mutations in a subset of Li-Fraumeni syndrome cancer-prone families that lack p53 alterations (18).

Apaf1 is critical for the induction of p53-dependent apoptosis and acts as a classical tumour suppressor (19). Soengas et al (20) showed by in vivo and in vitro experiments, that metastatic melanomas frequently lose functional Apaf1 due to promoter hypermethylation. Because of the resultant absolute inability to execute the typical apoptotic program in response to p53 activation, the demonstrated loss of the Apaf1 function also conferred striking chemoresistant properties to all of the respective tumour cells.

The cardinal TSG Rb1 controls the crucial G1/S cell cycle transition checkpoint. In its phosphorylated form Rb1 initiates the passage through the cell cycle via E2F release. The E2F release is indirectly influenced by p53 via p21 $1^{\mathrm{CIP} 1}$ activation, since activated p $21^{\mathrm{CIP} 1}$ inhibits CDK $4 / 6$ cyclin D complex-mediated Rb1 phosphorylation. Thus Rb1 can be regarded as an important p53 effector. The functional disruption of the Rb1 locus, due to defined genetic alterations (e.g. 
nonsense mutations) has been found in 4 of 22 (18\%) investigated human malignant melanoma (HMM) cell lines, as described in a previous study (21).

However, it is worth mentioning here, that besides the activated $\mathrm{p} 21^{\mathrm{CIP} 1}$, activated $\mathrm{p} 16^{\mathrm{INK} 4 \mathrm{a}}$, which is encoded by the CDKN2A gene locus, also inhibits the CDK 4/6 cyclin D complex-mediated Rb1 phosphorylation/E2F release. CDKN2A encodes for an additional protein ( $144^{\mathrm{ARF}}$ ) by using an alternative first exon (1ß) in alliance with the shared but frame-shifted exon 2 . The p14 ${ }^{\mathrm{ARF}}$ protein also displays an important function in cell cycle control. It has the ability to inactivate the oncoprotein $\mathrm{Mdm} 2$ and thereby prevents preliminary p53 degradation. Consequently, the inactivation of the entire CDKN2A gene locus abolishes the correct function of both the p53 as well as the Rb1 pathway $(22,23)$.

Most cancer therapies substantially rely on apoptosis induction within the particular tumour. Furthermore, it can be stated as a general rule, that most human tumours which exhibit a prominent resistance against radiation- and chemotherapy frequently harbour a mutated p53 gene. This fact can be explained by the pronounced apoptosis resistance of p53-deficient cancer cells due to their lack of Apaf1 induction capacity. Almost all HMMs exhibit an unusually pronounced resistance against radiation- and chemotherapy as well. However, in spite of their evident therapy resistance, p53 mutations in HMM can only very rarely be demonstrated. For example, in one particular study (24), only one of 119 primary human melanomas $(0.8 \%)$ and two of 92 metastases (2.2\%) displayed mutations in the p53 gene. However, because it is conceivable that certain alternative p53-pathway disruption mechanisms could be substantially involved in apoptosisresistant melanomas, we screened nine HMM cell lines for gene expression loss and mutations in three apoptosisassociated TSGs, which are localised upstream (Chk1, Chk2) and downstream (Apaf1) the pivotal p53 gene. In addition, we screened $\mathrm{Rb} 1$ as the fundamental regulator of the $\mathrm{G} 1 / \mathrm{S}$ cell cycle transition checkpoint.

A novel cDNA-based mutation screening strategy allowed the necessary fast but concurrently highly reliable and comprehensive analysis of the four relatively large genes (Chk1, 476 codons; Chk2, 543 codons; Rb1, 928 codons; and Apaf1, 1237 codons). Moreover, the new technique simultaneously enabled the characterization of point mutations and smaller deletions/insertions in alliance with the detection of gene expression loss (explainable either by methylation events or extended genomic deletions).

\section{Materials and methods}

HMM cell lines. Nine HMM cell lines obtained from two different sources were used in this study: Mel-HO, Fo-1, Mel-Kl.2, MRI-H-121B, MRI-H-221, SK-Mel5, SK-Mel28, (tumour bank, DKFZ, Heidelberg, Germany) as well as WM 1650 and GRM (a gift from Professor Dorothy Bennett, Department of Basic Medical Sciences, St. George's Hospital Medical School, London, UK).

Cell culture. Eight HMM cell lines were grown in RPMI1640 medium (Sigma), supplemented with 10\% FCS (Biochrom) and $0.5 \%$ penicillin/streptomycin $(10,000 \mathrm{U} / \mathrm{ml}$,
Sigma), according to the recommendations of the providers, and incubated under a humified atmosphere with $5 \% \mathrm{CO}_{2}$ at $37^{\circ} \mathrm{C}$. The cell line WM 1650 was incubated with $10 \% \mathrm{CO}_{2}$ plus an additional $200 \mathrm{nM}$ tetradecanoyl phorbol acetate and 200 pM cholera toxin (Sigma) under otherwise identical conditions. The cells were grown in $75 \mathrm{~cm}^{2}$ culture flasks (TPP), supplemented with new medium $3 x$ per week and passaged according to their requirements. For RNA isolation, the cells were washed with PBS (PromoCell) at 70\% confluency and harvested with $0.1 \%$ trypsin (Sigma) in PBS.

RNA isolation and cDNA synthesis. Total cellular RNA was isolated by using the RNeasy mini kit, (Qiagen), following the guidelines of the manufacturer, and finally stored at $-80^{\circ} \mathrm{C}$ until further use. RNA derived from the blood of a healthy person was isolated with the ENZA ${ }^{\circledR}$ Blood RNA kit (Peqlab) and used as the wild-type control. The RNA quality was determined on a formaldehyde agarose gel and its quantity was determined by measuring the absorbance at $260 \mathrm{~nm}$ by using a spectrophotometer (GeneQuant RNA/DNA Calculator, Pharmacia).

cDNA synthesis from total cellular RNA was carried out by using the 1 st strand cDNA synthesis kit for RT-PCR (AMV) by Roche according to the guidelines of the manufacturer $\left(10 \mathrm{~min}\right.$ at $25^{\circ} \mathrm{C} ; 60 \mathrm{~min}$ at $42^{\circ} \mathrm{C} ; 10 \mathrm{~min}$ at $95^{\circ} \mathrm{C}$; cDNA storage at $-20^{\circ} \mathrm{C}$ until further use).

cDNA-based SSCP/DGGE analysis. Specific primer pairs, which generated overlapping sequences, covering the entire open reading frame (ORF) of the tumour suppressor genes Chk1, Chk2, Apaf1 and RB1 were designed by using the cDNA sequences available on Public Medline (http:// www.ncbi.nlm.nih.gov) and the OLIGO software (Hitachi). All PCR reactions were accomplished on the Mastercycler Gradient (Eppendorf) and the generated PCR products were quality-controlled by agarose gel electrophoresis. The primers were purchased from MWG-Biotech. In a first approach, their locations were chosen in order to amplify a few long PCR products. These were then used in a second (semi-) nested PCR as a template to create short overlapping fragments, which were optimised in regard to their suitability for subsequent combined SSCP/DGGE analysis (German patent no. 19825314, dated 22.04.2004, Dr Thilo Papp). The novel screening strategy is described in detail by Kumar et al (25). All positive screening results were confirmed by the repetition of the whole screening protocol from the beginning using new cDNA. For available detailed computerized information about the primers and PCR conditions for the analysis of Chk1 (2 pre-amplifications, 8 re-amplifications), Chk2 (2 preamplifications, 8 re-amplifications), Apaf1 (5 pre-amplifications, 13 re-amplifications) and Rb1 (4 pre-amplifications, 17 re-amplifications), please contact the corresponding author.

\section{Results}

In two of the nine investigated cell lines (22\%) alterations of the investigated genes could be demonstrated. In the cell line GRM, a loss of wild-type gene expression was detected in three (Chk2, Apaf1 and Rb1) of the four investigated genes 


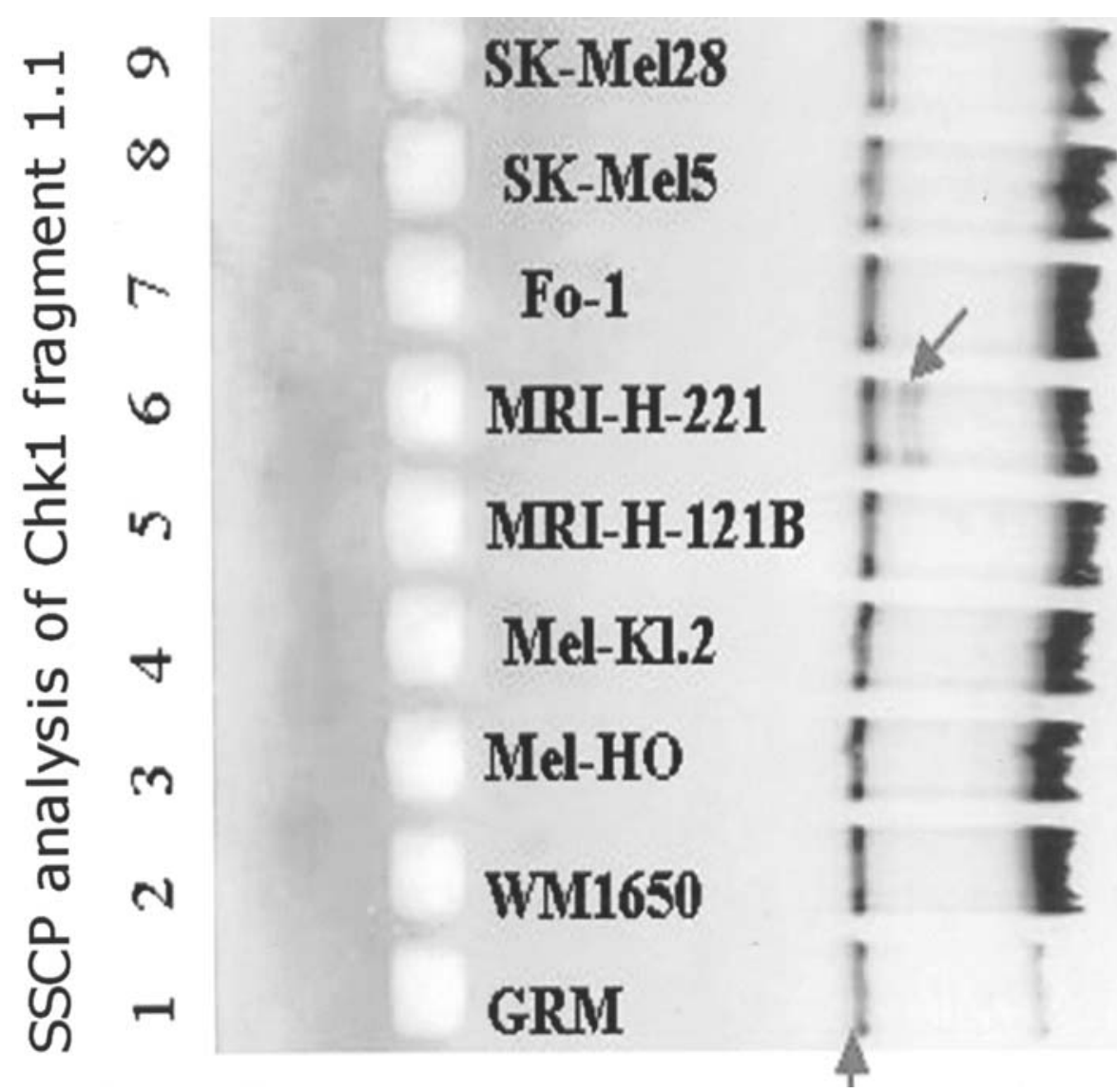

Figure 1. SSCP analysis of the Chk1 gene fragment 1.1. The lower arrow indicates the aberrantly migrating SSCP double band in the MRI-H-221 cell line, which was later shown to harbour a 13-bp deletion by subsequent upstream and downstream sequencing (Fig. 2).

(data not shown). i) In Chk2 one of the two gene fragments (pre-amplification fragment 2, comprising of $933 \mathrm{bp}$ ) could not be amplified by cDNA-based PCR. ii) In the Apaf1 gene four of the five cDNA-based pre-amplifications (fragments $1,2,3$, and 4, comprising of $971,1132,983$ and $936 \mathrm{bp}$, respectively) produced no results. iii) In Rb1 two of the four gene fragments (pre-amplification fragments 1 and 2, comprising of 976 and 989 bp, respectively) could not be amplified by cDNA-based PCR.

The specific PCR fragment losses were further confirmed by supplementary multiplex PCR using new cDNA as the template. For this purpose, the primers for the relevant reamplification fragments were used together directly with a primer pair for a housekeeping gene fragment (GADPH) in a co-amplification strategy.

As a whole, our data undoubtedly point to totally nonfunctional Chk2, Apaf1 and Rb1 genes, probably due to the extended partial mRNA deletions of the one allele in alliance with the whole gene deletions or the promoter methylationmediated expression loss of the other one. Consequently, in the GRM cell line, both the Rb1 as well as the p53 pathway are substantially damaged.

In the cell line MRI-H-221 a mutation of the Chk1 gene was demonstrated. The mutation was detected by SSCP screening due to an aberrant double band, which represents the mutated re-amplification fragment 1.1 (Fig. 1).

The sequencing of fragment 1.1 in both directions and subsequent sequence data analysis revealed a 13-bp deletion (the loss of bases 53 to 65 of the coding sequence) in alliance with the wild-type allele (demonstrable in both sequencing directions due to the abrupt manifestation of overlapping curves at a definite sequencing position - base pair position 53 at the codon strand and base pair position 65 at the anticodon strand) (Fig. 2). The 13-bp deletion (gtgcc tatgg aga), which apart from amino acid sequence information loss also caused a reading frame shift, affected the second base of codon 18 (as a result GGT -Gly- changed to GAG -Glu-, etc). In addition, a first stop codon (TGA) was generated at codon 23 of the deleted and frame-shifted allele (the same thing occured at codons $26,33,36$, etc). On the whole, the 13-bp deletion resulted in an absolutely non-functional Chk1 allele in the cell line MRI-H-221.

In principle, the functional loss of a TSG allele causes only limited effects on a specific tumour. However, within an assumed potential tumour cell subpopulation, the demonstrated Chk1 mutation in MRI-H-221 would have a tremendous impact, despite the still detectable wild-type allele.

\section{Discussion}

Despite the limited sample numbers, our preliminary results confirm the hypothesis of the participation of dysfunctional p53 inducer/effecter genes in HMM aetiology (functional loss of Chk2, Apaf1 and Rb1 in GRM; functional loss of Chk1 in an assumed subpopulation of MRI-H-221). More indirectly, the data also point to a possible key role of diverse alternative 
sequencing of MRI-H-221 at the codon strand of Chk1 fragment 1.1

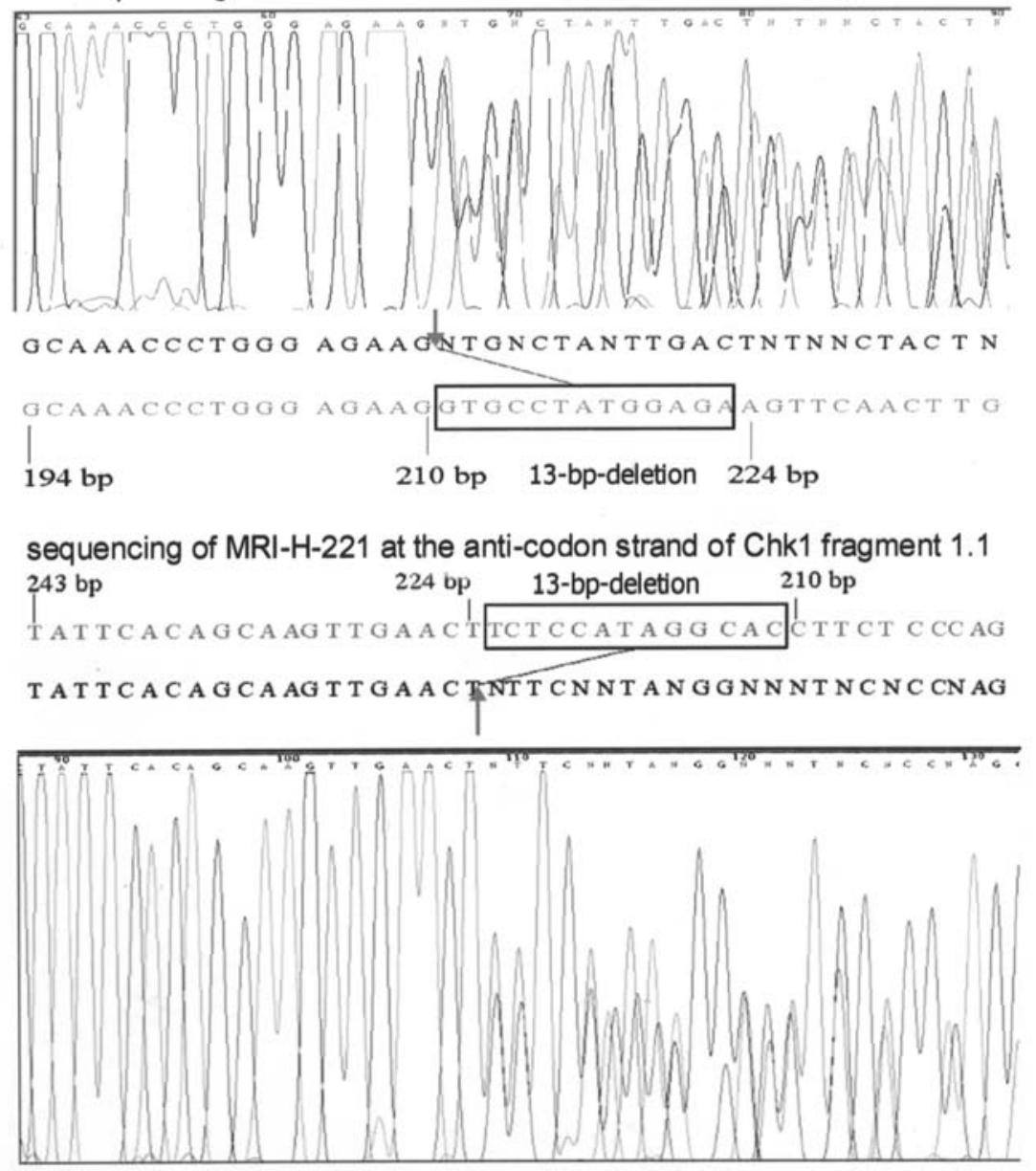

Figure 2. Sequencing of the Chk1 gene fragment 1.1 of MRI-H-221 in both directions revealed a 13-bp deletion in alliance with the wild-type allele. The 13-bp deletion caused a loss of the coding sequence bases 53 to 65 and a reading frame shift. As a result GGT -Gly- at codon position 18 is changed to GAG -Glu-, etc. Furthermore, a first newly generated stop codon (TGA) arose at codon position 23 of the mutated allele (not visible here).

p53-pathway disruption mechanisms in the particular fraction of highly therapy-resistant tumours, which evidently do not display a direct functional loss of the pivotal p53 gene itself. Nonetheless, the analysis of larger numbers of cell lines, primary tumours, and metastases is urgently needed in the future, in order to achieve more defined conclusions about the actual relevance of such genetic alterations in HMM aetiology. Therefore, further checkpoint pathway-associated genes (e.g. ATM and ATR, as directly associated upstream genes) are potential candidates for mutational screening in forthcoming studies.

Concerning the coincident functional loss of the p53 and Rb1 pathways, our findings in GRM are supported by the results of two more recent studies. Daniotti et al (26) and Yang et al (27) investigated 39 and 36 HMM cell lines for mutations in $\mathrm{p} 16^{\mathrm{INK} 4 \mathrm{a}}, \mathrm{p} 14^{\mathrm{ARF}}, \mathrm{p} 53$ (exons 4-10) and CDK4 (exon 2), respectively. The mutational screening of Rb1 was not accomplished in either of these investigations. Overall, mutations were found in $53(70.7 \%)$ of the 75 analysed cell lines, which simultaneously compromise the p53 as well as the Rb1 pathway. Thereby, the homozygous deletion of all three critical CDKN2A exons (exons $1 \beta, 1 \alpha$ and 2) represented the most common mutational mechanism $(n=22,41.5 \%$ of the dual pathway-compromised cell lines), followed by point mutations or frame shift mutations at CDKN2A exon $2(\mathrm{n}=7$, $13.2 \%$ ), concomitant deletions of CDKN2A exon $1 \alpha$ and exon $2(n=7,13.2 \%)$ and other mutational combinations at the CDKN2A locus $(n=6,11.3 \%)$. Because in all these cases (overall, $\mathrm{n}=42,79.2 \%$ ) no p53 mutations were detectable, these findings impressively underline the general significance of alternative p53-inactivating mechanisms in HMM aetiology. In contrast, CDKN2 alterations in alliance with p53 mutations and concomitant mutations in p53 and CDK4, were only found in seven and four dual pathway-mutated HMM cell lines, respectively (overall, $n=11,20.8 \%$ ). p53 mutations were detected in 6 of the investigated cell lines exclusively, and in a further 14 CMMs, no gene mutations could be demonstrated at CDKN2A, CDK4, or p53. However, in this context it should be considered that an $\mathrm{Rb} 1$ analysis was not included in either study and that a CDKN2A locus inactivation can also be caused by epigenetic or posttranslational mechanisms (actually 5 of the 14 CMMs with absent gene mutations were additionally analysed for $\mathrm{p} 16^{\mathrm{INK} 4 \mathrm{a}}$ protein expression loss by Western blotting; all of them exhibited strongly diminished $\mathrm{p} 16^{\mathrm{INK} 4 \mathrm{a}}$ expression, ranging from $0,7,8,14$, up to $52 \%$ maximum). Moreover, p53 inducer 
and effector genes such as ATM, ATR, Chk1, Chk2 or Apaf1, which, according to our results, clearly represent potential alternative mutational targets, were not investigated.

In this context, another aspect evolves by comparing the mutational spectra of human melanocytic naevi and HMM. Although human naevi, as a focal aggregation of non-dendritic melanocytes, have been suggested to be replicative senescent cell clones (28), they are also unambiguously considered as potential pre-malignant lesions. Several studies have strongly indicated an aetiological connection between melanocytic naevi and cutaneous melanomas. As a whole, the development of approximately one-third of all cutaneous melanomas occurs within the setting of a pre-existing melanocytic naevus (29-31). With regard to the coincident activation of specific oncogenes in spatially linked melanocytic lesions, Demunter et al (32) demonstrated identical N-ras mutations in congenital or dysplastic melanocytic naevi (CMN, DMN) and their adjacent melanomas. Such findings strongly support the notion that certain naevi actually constitute melanoma precursors. In one particular study, a genome-wide mutation detection strategy revealed alterations in the BRAF gene in a high proportion of melanoma cell lines and primary tumours (33). Subsequent studies later demonstrated remarkably high frequencies of particularly BRAF but also N-ras mutations in both cutaneous malignant melanomas and melanocytic naevi (34-42). Because BRAF and N-ras mutations are roughly equivalent regarding their capacity in the constitutive MAPK pathway activation, they were generally found with mutual exclusion in all of the concurrently investigated melanocytic lesions. The previously reported N-ras-based clonal relationship between cutaneous naevi and adjacent melanomas were further confirmed in a study by Yazdi et al (43). In 13 of the 14 cases (93\%), they detected the BRAF V600E hot spot mutation either in the naevus and its corresponding melanoma, or both lesions harboured wildtype alleles.

However, the most striking genetically based difference between benign melanocytic lesions and malignant melanomas is the additional involvement of alterations in $\mathrm{p} 16^{\mathrm{INK} 4 \mathrm{a}}$, p14 ${ }^{\mathrm{ARF}}, \mathrm{CDK} 4$ or p53 in the malignancies. In a former study, by analysing $18 \mathrm{CMN}$ and $18 \mathrm{DMN}$ lesions, we could not demonstrate a single alteration in either one of these genes (44). In agreement with our results, Kumar et al (41) found no p16 $16^{\text {INK4a }}$ mutations in 27 investigated commonly acquired melanocytic naevi. In contrast, 34 of the 35 melanoma lesions with N-ras or BRAF mutations, characterized by Daniotti et al (26), simultaneously harboured additional single or even variably combined mutations at p16 $6^{\mathrm{INK} 4 \mathrm{a}}(\mathrm{n}=32), \mathrm{p} 14^{\mathrm{ARF}}$ $(\mathrm{n}=24), \mathrm{p} 53(\mathrm{n}=10)$ and CDK4 $(\mathrm{n}=1)$. Sasaki et al $(45)$ also reported the homozygous deletion of $\mathrm{p} 16^{\mathrm{INK} 4 \mathrm{a}} / \mathrm{P} 14^{\mathrm{ARF}}$ and the BRAF V600E hot spot mutation as concomitant alterations in two of six $(33 \%)$ investigated melanoma cell lines. The investigation of CDK4 and p53 was not performed in their study.

In view of the data mentioned above, it is conceivable that particularly a parallel mutational screening of melonocytic naevi, their spatially linked melanomas and associated metastases, will provide detailed insights into the distinct order of the numerous successive mutational steps, which, in variable combinations, are necessary for the initial formation and the continued progression of HMM. Consequently, in forthcoming studies, fast and reliable cDNA-based microarray gene expression profiling techniques, including all known HMM-associated genes should be accomplished in solitary HMM but particularly in spatially associated melanocytic naevi/HMM samples (by laying emphasis on the different lesion subgroups). Short-term cell lines of the different melanocytic lesions would also permit the subsequent simultaneous distribution of relevant samples in adequate quantities to different highly specialised laboratories, in order to assess the extent of the specific genetic alterations in the respective lesions.

\section{Acknowledgements}

This investigation was supported by the EC grant QLK41999-01084 (MAUVE) and by the German Federal Ministry of Education and Research (BMBF). We thank Heidi Pemsel for excellent technical support.

\section{References}

1. Sanchez Y, Wong C, Thoma RS, Richman R, Wu Z, PiwnicaWorms $\mathrm{H}$ and Elledge SJ: Conservation of the Chk1 checkpoint pathway in mammals: linkage of DNA damage to Cdk regulation through Cdc25. Science 277: 1497-1501, 1997.

2. Liu Q, Guntuku S, Cui XS, Matsuoka S, Cortez D, Tamai K, Luo G, Carattini-Rivera S, DeMayo F, Bradley A, Donehower LA and Elledge SJ: Chk1 is an essential kinase that is regulated by Atr and required for the G(2)/M DNA damage checkpoint. Genes Dev 14: 1448-1459, 2000.

3. Zhao $\mathrm{H}$ and Piwnica-Worms H: ATR-mediated checkpoint pathways regulate phosphorylation and activation of human Chk1. Mol Cell Biol 21: 4129-4139, 2001.

4. Zhao H, Watkins JL and Piwnica-Worms H: Disruption of the checkpoint kinase 1 /cell division cycle $25 \mathrm{~A}$ pathway abrogates ionizing radiation-induced $\mathrm{S}$ and $\mathrm{G} 2$ checkpoints. Proc Natl Acad Sci USA 99: 14795-14800, 2002.

5. Mailand N, Falck J, Lukas C, Syljuasen RG, Welcker M, Bartek J and Lukas J: Rapid destruction of human Cdc25A in response to DNA damage. Science 288: 1425-1429, 2000.

6. Mailand N, Podtelejnikov AV, Groth A, Mann M, Bartek J and Lukas J: Regulation of G(2)/M events by Cdc25A through phosphorylation-dependent modulation of its stability. EMBO J 21: 5911-5920, 2002.

7. Matsuoka S, Huang M and Elledge SJ: Linkage of ATM to cell cycle regulation by the Chk 2 protein kinase. Science 282 : 1893-1897, 1998.

8. Brown AL, Lee CH, Schwarz JK, Mitiku N, Piwnica-Worms H and Chung JH: A human Cds1-related kinase that functions downstream of ATM protein in the cellular response to DNA damage. Proc Natl Acad Sci USA 96: 3745-3750, 1999.

9. Chaturvedi P, Eng WK, Zhu Y, Mattern MR, Mishra R, Hurle MR, Zhang X, Annan RS, Lu Q, Faucette LF, Scott GF, Li X, Carr SA, Johnson RK, Winkler JD and Zhou BB: Mammalian Chk2 is a downstream effector of the ATM-dependent DNA damage checkpoint pathway. Oncogene 18: 4047-4054, 1999.

10. Zhou BB, Chaturvedi P, Spring K, Scott SP, Johanson RA, Mishra R, Mattern MR, Winkler JD and Khanna KK: Caffeine abolishes the mammalian G2/M DNA damage checkpoint by inhibiting Ataxia-Telangiectasia-mutated kinase activity. J Biol Chem 275: 10342-10348, 2000.

11. Matsuoka S, Rotman G, Ogawa A, Shiloh Y, Tamai K and Elledge SJ: ATM phosphorylates Chk2 in vivo and in vitro. Proc Natl Acad Sci USA 97: 10389-10394, 2000.

12. Melchionna R, Chen XB, Blasina A and McGowan CH: Threonine 68 is required for radiation-induced phosphorylation and activation of Cds1. Nat Cell Biol 2: 762-765, 2000.

13. O'Neill T, Giarratani L, Chen P, Iyer L, Lee CH, Bobiak M, Kanai F, Zhou BB, Chung JH and Rathbun GA: Determination of substrate motifs for human Chk1 and hCds1/Chk2 by the oriented peptide library approach. J Biol Chem 277: 16102-16115, 2002. 
14. Falck J, Lukas C, Protopopova M, Lukas J, Selivanova G and Bartek J: Functional impact of concomitant versus alternative defects in the Chk2-p53 tumour suppressor pathway. Oncogene 20: 5503-5510, 2001.

15. Hirao A, Cheung A, Duncan G, Girard PM, Elia AJ, Wakeham A, Okada H, Sarkissian T, Wong JA, Sakai T, De Stanchina E, Bristow RG, Suda T, Lowe SW, Jeggo PA, Elledge SJ and Mak TW: Chk2 is a tumor suppressor that regulates apoptosis in both an ATM-dependent and ATM-independent manner. Mol Cell Biol 22: 6521-6532, 2002.

16. Chehab NH, Malikzay A, Appel M and Halazonetis TD: Chk2/hCds 1 functions as a DNA damage checkpoint in $\mathrm{G}(1)$ by stabilizing p53. Genes Dev 14: 278-288, 2000.

17. Shieh SY, Ahn J, Tamai K, Taya Y and Prives C: The human homologs of checkpoint kinases Chk1 and Cds1 (Chk2) phosphorylate p53 at multiple DNA damage-inducible sites. Genes Dev 14: 289-300, 2000.

18. Bell DW, Varley JM, Szydlo TE, Kang DH, Wahrer DC, Shannon KE, Lubratovich M, Verselis SJ, Isselbacher KJ, Fraumeni JF, Birch JM, Li FP, Garber JE and Haber DA: Heterozygous germ line hCHK2 mutations in Li-Fraumeni syndrome. Science 286: 2528-2531, 1999.

19. Macleod K: Tumor suppressor genes. Curr Op in Genet Dev 10: 81-93, 2000.

20. Soengas MS, Capodieci P, Polsky D, Mora J, Esteller M, Opitzaraya X, McCombie R, Herman JG, Gerald WL, Lazebnik YA, Cordòn-Cardò $C$ and Lowe SW: Inactivation of the apoptosis effector Apaf-1 in malignant melanoma. Nature 409: 207-211, 2001.

21. Bartkova J, Lukas J, Guldberg P, Alsner J, Kirkin AF, Zeuthen J and Bartek J: The p16-cyclin D/Cdk4-pRb pathway as a functional unit frequently altered in melanoma pathogenesis. Cancer Res 56: 5475-5483, 1996.

22. Quelle DE, Zindy F, Ashmun RA and Sherr CJ: Alternative reading frames of the INK4a tumor suppressor gene encode two unrelated proteins capable of inducing cell cycle arrest. Cell 83: 993-1000, 1995.

23. Chin L, Pomerantz J and DePinho RA: The INK4a/ARF tumor suppressor: one gene - two products - two pathways. Trends Biochem Sci 23: 291-296, 1998.

24. Papp T, Jafari M and Schiffmann D: Lack of p53 mutations and loss of heterozygosity in non-cultured melanocytic lesions. J Cancer Res Clin Oncol 122: 541-548, 1996.

25. Kumar K, Rahman Q, Schipper H, Matschegewski C, Schiffmann D and Papp T: Mutational analysis of 9 different tumour-associated genes in human malignant mesothelioma cell lines. Oncol Rep 14: 743-750, 2005.

26. Daniotti M, Oggionni M, Ranzani T, Vallacchi V, Campi V, Di Stasi D, Della Torre G, Perrone F, Luoni C, Suardi S, Frattini M, Pilotti S, Anichini A, Tragni G, Parmiani G, Pierrotti MA and Rodolfo M. BRAF alterations are associated with complex mutational profiles in malignant melanoma. Oncogene 23: 5968-5977, 2004.

27. Yang G, Rajadurai A and Tsao $\mathrm{H}$ : Recurrent patterns of dual $\mathrm{Rb}$ and p53 pathway inactivation in melanoma. J Invest Dermatol 125: 1242-1251, 2005.

28. Bennett DC: Human melanocyte senescence and melanoma susceptibility genes. Oncogene 22: 3063-3069, 2003.

29. Harley S and Walsh N: A new look at nevus-associated melanomas. Am J Dermatopathol 18: 137-141, 1996.

30. Massi D, Carli P, Franchi A and Santucci M: Naevus-associated melanomas: cause or chance? Melanoma Res 9: 85-91, 1999.

31. Stante M, Carli P, Massi D and de Giorgi V: Dermoscopic features of naevus-associated melanoma. Clin Exp Dermatol 28: 476-480, 2003.

32. Demunter A, Stas M, Degreef H, de Wolf-Peeters C and van den Oord JJ: Analysis of N- and K-ras mutations in the distinctive tumor progression phases of melanoma. J Invest Dermatol 117: 1483-1489, 2001.
33. Davies H, Bignell GR, Cox C, Stephens P, Edkins S, Clegg S, Teague J, Woffendin H, Garnett MJ, Bottomley W, Davis N, Dicks E, Ewing R, Floyd Y, Gray K, Hall S, Hawes R, Hughes J, Kosmidou V, Menzies A, Mould C, Parker A, Stevens C, Watt S, Hooper S, Wilson R, Jayatilake H, Gusterson BA, Cooper C, Shipley J, Hargrave D, Pritchard-Jones K, Maitland N, Chenevix-Trench G, Riggins GJ, Bigner DD, Palmieri G, Cossu A, Flanagan A, Nicholson A, Ho JW, Leung SY, Yuen ST, Weber BL, Seigler HF, Darrow TL, Paterson H, Marais R, Marshall CJ, Wooster R, Stratton MR and Futreal PA: Mutations of the BRAF gene in human cancer. Nature 417: 949-954, 2002.

34. Kumar R, Angelini S, Czene K, Sauroja I, Hahka-Kemppinen M, Pyrhönen S and Hemminki K: BRAF mutations in metastatic melanoma: A possible association with clinical outcome. Clin Cancer Res 9: 3362-3368, 2003.

35. Brose MS, Volpe P, Feldman M, Kumar M, Rishi I, Gerrero R, Einhorn E, Herlyn M, Minna J, Nicholson A, Roth JA, Albelda SM, Davies H, Cox C, Brignell G, Stephens P, Futreal PA, Wooster R, Stratton MR and Weber BL: BRAF and RAS mutations in human lung cancer and melanoma. Cancer Res 62: 6997-7000, 2002

36. Pollock PM, Harper UL, Hansen KS, Yudt LM, Stark M, Robbins CM, Moses TY, Hostetter G, Wagner U, Kakareka J, Salem G, Pohida T, Heenan P, Duray P, Kallioniemi O, Hayward NK, Trent JM and Meltzer PS: High frequency of BRAF mutations in nevi. Nat Genet 33: 19-20, 2003.

37. Kumar R, Angelini S and Hemminki K: Activating BRAF and $\mathrm{N}$-ras mutations in sporadic primary melanomas: An inverse association with allelic loss on chromosome 9. Oncogene 22: 9217-9224, 2003

38. Omholt K, Platz A, Kanter L, Ringborg U and Hansson J: NRAS and BRAF mutations arise early during melanoma pathogenesis and are preserved throughout tumor progression. Clin Cancer Res 9: 6483-6488, 2003.

39. Gorden A, Osman I, Gai W, He D, Huang W, Davidson A, Houghton AN, Busam K and Polsky D: Analysis of BRAF and N-RAS mutations in metastatic melanoma tissues. Cancer Res 63: 3955-3957, 2003

40. Houben R, Becker JC, Kappel A, Terheyden P, Bröcker E-B, Goetz R and Rapp UR: Constitutive activation the Ras-Raf signaling pathway in metastatic melanoma is associated with poor prognosis. J Carcinog 3: 1-13, 2004.

41. Kumar R, Angelini S, Snellman E and Hemminki K: BRAF mutations are common somatic events in melanocytic nevi. J Invest Dermatol 122: 342-348, 2004.

42. Lang J, Boxer M and MacKie R: Absence of exon 15 germline mutations in familial melanoma. Hum Mutat 21: 327-330, 2003.

43. Yazdi AS, Palmedo G, Flaig MJ, Puchta U, Reckwerth A, Rütten A, Mentzel T, Hügel H, Hantschke M, SchmidtWendtner M-H, Kutzner H and Sander CA: Mutations of the BRAF gene in benign and malignant melanocytic lesions. J Invest Dermatol 121: 1160-1162, 2003.

44. Papp T, Schipper H, Kumar K, Schiffmann D and Zimmermann R: Mutational analysis of the BRAF gene in human congenital and dysplastic melanocytic naevi. Melanoma Res 15: 401-407, 2005.

45. Sasaki Y, Niu C, Makino R, Kudo C, Sun C, Watanabe H, Matsunaga J, Takahashi K, Tagami H, Aiba S and Horii A: Braf point mutations in primary melanoma show different prevalences by subtype. J Invest Dermatol 123: 177-183, 2004. 